\title{
Karakteristik dan Stabilitas Fisik NLC-Koenzim Q10 dalam Sleeping Mask dengan Minyak Nilam
}

\section{Characteristics and Physical Stability of NLC-Coenzyme Q10 in Sleeping Mask with Patchouli Oil}

Fransisca Dita Mayangsari ${ }^{1}$, Tristiana Erawati ${ }^{2}$, Widji Soeratri ${ }^{2}$, Noorma Rosita ${ }^{2}$

${ }^{1}$ Program Studi Magister Ilmu Farmasi, Fakultas Farmasi, Universitas Airlangga, Surabaya, Indonesia

${ }^{2}$ Departemen Ilmu Kefarmasian, Fakultas Farmasi, Universitas Airlangga, Surabaya, Indonesia

*Corresponding author: era_ffua@yahoo.co.id

Submitted: 29 Januari 2021

Accepted: 2 Maret 2021

Published: 29 Agustus 2021

\begin{abstract}
Introduction: patchouli oil has an antioxidant and penetration-enhancing effect. The oil potentially increased the effectiveness of sleeping mask with Coenzyme Q10 (CoQ10) in Nanostructured Lipid Carriers (NLC) as an antiaging cosmetic. Objective: To observed the physical characteristics and stability of NLC-CoQ10 in sleeping masks compared to NLC-CoQ10 in sleeping masks with 1\% patchouli oil. Methods: The preparation of NLC-CoQ10 was using the High Shear Homogenization method. NLC-CoQ10 was mix with hydrogel and patchouli oil for F2. While for F1 without patchouli oil. After that, physical characteristics and stability were observed, included organoleptic, $\mathrm{pH}$, and viscosity. Physical stability test observed at room temperature for 90 days. Results: The physical characteristics test showed that F1 had an odor like oleum cacao, while F2 had a specific odor of patchouli oil and a slight odor like oleum cacao. F1 had $6.036 \pm 0.011$ for $\mathrm{pH}$ value, while F2 had $6.062 \pm 0.020$. There is no significant difference. However, F1 and F2 have different viscosity values. F1 had $199.2 \pm 0.7 \mathrm{cp}$ for viscosity value, while $F 2$ had $175.6 \pm 7.9 \mathrm{cp}$. The physical stability test showed that $F 1$ and $F 2$ had $p H$ value scale ranges from 6.055 - 6.336 and viscosity $175.6-239.7 \mathrm{cp}$. The viscosity value of $F 1$ had increased after the 60th day, while F2 on the 90th day. Conclusion: Based on characteristic and physical stability tests can be concluded that F1 and $F 2$ have different odor and viscosity, and F2 is more stable than F1.
\end{abstract}

Keywords: sleeping mask, nanostructured lipid carriers (NLC), coenzyme Q10, patchouli oil

\begin{abstract}
Abstrak
Pendahuluan: Minyak nilam memiliki efek antioksidan dan peningkat penetrasi. Minyak tersebut berpotensi meningkatkan efektivitas produk sleeping mask dengan Koenzim Q10 (KoQ10) yang dimuat dalam Nanostructured Lipid Carriers (NLC) sebagai kosmetik anti-penuaan. Tujuan: Membandingkan karakteristik dan stabilitas fisik dari NLC-KoQ10 yang dimuat dalam sleeping mask dengan dan tanpa minyak nilam. Metode: Preparasi NLC-KoQ10 menggunakan metode High Shear Homogenization. NLC-KoQ10 dicampur dengan hydrogel dan minyak nilam, untuk F2. Sedangkan untuk F1 tanpa minyak nilam. Setelah itu diamati karakteristik dan stabilitas fisiknya yang meliputi organoleptik, $\mathrm{pH}$, dan viskositas. Uji stabilitas fisik diamati pada suhu ruang selama 90 hari. Hasil: Uji karakteristik fisik menunjukkan bahwa F1 memiliki bau seperti oleum cacao, sedangkan F2 memiliki bau khas minyak nilam dan sedikit bau seperti oleum cacao. F1 memiliki nilai pH 6,036 $\pm 0,011$, sedangkan F2 memiliki nilai pH 6,062 $\pm 0,020$. Tidak ada perbedaan yang signifikan. Namun, F1 dan F2 memiliki nilai viskositas yang berbeda. F1 memiliki nilai viskositas 199,2 $\pm 0,7 \mathrm{cp}$, sedangkan F2 memiliki nilai viskositas 175,6 \pm 7,9 cp. Uji stabilitas fisik menunjukkan bahwa F1 dan F2 memiliki skala nilai pH berkisar 6,055 - 6,336 dan viskositas 175,6 - 239,7 cp. Nilai viskositas F1 mengalami peningkatan setelah hari ke-60, sedangkan F2 pada hari ke-90. Kesimpulan: Berdasarkan uji karakteristik dan stabilitas fisik dapat disimpulkan bahwa F1 dan F2 memiliki bau dan viskositas yang berbeda, dan F2 lebih stabil daripada F1.
\end{abstract}

Kata kunci: sleeping mask, Nanostructured Lipid Carriers (NLC), Koenzim Q10, minyak nilam 


\section{PENDAHULUAN}

Kulit adalah jaringan terluar dan organ terbesar dari tubuh manusia, luas permukaanya sekitar $1-2 \mathrm{~m}^{2}$ atau sekitar $12-15 \%$ dari total berat tubuh (Science, 2009). Sama seperti organ yang lain, kulit juga akan mengalami penuaan seiring berjalannya waktu. Penuaan kulit, ditandai dengan perubahan penampilan pada kulit, seperti kulit yang kering, timbulnya kerutan, berkurangnya elastisitas dan munculnya binik-bintik hitam (Campa \& Baron, 2018; Mitsui, 1998). Untuk memperlambat proses penuaan kulit, maka kulit harus dirawat. Salah satu cara untuk merawat kulit adalah dengan memakai serangkaian produk perawatan kulit. Salah satu jenis produk perawatan kulit yang sedang banyak dikembangkan oleh industri kosmetik saat ini adalah sleeping mask.

Sleeping mask adalah salah satu produk perawatan kulit yang digunakan pada malam hari (saat waktu tidur). Produk ini diaplikasikan ke seluruh wajah kecuali kedua mata dan mulut, kemudian dibilas dengan air pada keesokan harinya. Produk ini biasanya memiliki konsistensi semipadat seperti gel dan dikemas dalam wadah pot (Yang dkk., 2019). Sleeping mask merupakan salah satu contoh masker wajah yang mengandung moisturizer dan berfungsi untuk melembabkan kulit (Nilforoushzadeh dkk., 2018). Selain mengandung moisturizer, sleeping mask juga dapat ditambah dengan bahan aktif lain, seperti agen anti-pigmentasi ataupun agen anti-penuaan kulit.

Pada penelitian ini, akan dikembangkan produk sleeping mask dengan basis hydrogel. Basis hydrogel dipilih karena dapat memberi efek menyegarkan dan melembutkan pada kulit (Nilforoushzadeh dkk., 2018). Bahan aktif yang digunakan untuk produk sleeping mask ini adalah Koenzime Q10.

Koenzime Q10 (KoQ10) atau Ubikuinon adalah suatu material larut lemak yang dapat mencegah terjadinya per-oksidasi lipid, sehingga dapat mencegah kerusakan kolagen dan elastine dan membantu menghindari kerut pada kulit (Bank dkk., 2010; Korkmaz dkk, 2013). KoQ10 adalah agen potensial dalam mencegah kerusakan kulit akibat photo-aging (Yue dkk., 2010). Namun, KoQ10 memiliki beberapa kekurangan, diantaranya kelarutan dalam air yang rendah $(0,193 \mu \mathrm{g} / \mathrm{mL}$ dalam air), berat molekul yang besar $(863,36 \mathrm{~g} / \mathrm{mol})$, dan memiliki lipofilisitas tinggi ( $\log \mathrm{P}>10$ ) (Lucangioli \& Tripodi, 2012). Sehingga penetrasinya melalui kulit menjadi rendah. Selain itu, KoQ10 juga mudah terdegradasi oleh cahaya dan suhu tinggi (Bao dkk., 2019). Untuk mengatasi hal-hal tersebut, maka diperlukan suatu strategi formulasi.
Salah satu contohnya adalah dengan memformulasikan KoQ10 dalam sistem NLC.

NLC (Nanostructured Lipid Carriers) adalah suatu sistem penghantar obat berukuran nano yang pada umumnya tersusun oleh lipid padat, lipid cair dan emulsifier (Kaur dkk., 2015). NLC merupakan generasi kedua dari SLN (Solid Lipid Nanopartikel). Beberapa keunggulan NLC yang tidak dimiliki oleh SLN antara lain tingginya daya penjebakan bahan aktif dan rendahnya pengusiran bahan aktif dari matriks lipid selama penyimpanan. Hal ini dikarenakan adanya tambahan lipid cair pada NLC. Lipid cair dapat menurunkan kristalinitas dan meningkatkan ketidakteraturan pada struktur matriks NLC, sehingga memberi banyak ruang untuk menampung bahan aktif. Hal ini sangat berbeda dengan SLN yang hanya tersusun dari lipid padat. Matriks lipid yang terbuat dari lipid padat cenderung membentuk kisi kristal yang sempurna, sehingga hanya menyisakan sedikit ruang untuk menampung bahan aktif (Fang dkk., 2013). NLC mampu melindungi bahan aktif dalam matriks lipid. Sehingga stabilitas bahan aktif menjadi meningkat (Muller dkk., 2014). Selain itu, NLC juga dapat meningkatkan kelarutan bahan aktif yang sukar larut dalam air. Sanad dkk (2010) mengatakan bahwa Oksibenzon yang bersifat lipofilik dapat dengan mudah bercampur dengan gel setelah dijebak dalam sistem NLC yang tersusun dari gliseril monostearat (lipid padat), Miglyol 812 dan asam oleat (lipid cair) dan polivinil alkohol (stabilizer).

Secara teori, formulasi KoQ10 dalam sistem NLC akan menghasilkan sediaan yang stabil, memiliki penetrasi melalui kulit yang tinggi dan efektivitas antipenuaan kulit yang tinggi. Namun, menurut penelitian yang telah dilakukan oleh Shoviantari (2017), KoQ10 dalam sistem NLC yang terbuat dari minyak zaitun, setil palmitate, tween 80 , span 80 , etanol 96 dan dapar asetat $\mathrm{pH} 4,2 \pm 0,2$ memiliki penetrasi yang lebih rendah dibandingkan dengan penetrasi KoQ10 dalam sistem nanoemulsi (NE) dengan bahan yang sama tetapi tanpa lipid padat (setil palmitat). Guna mengatasi permasalahan ini, maka perlu ditambahkan suatu bahan untuk meningkatkan penetrasi. Salah satu contohnya adalah minyak nilam.

Minyak minyak nilam (patchouli oil) adalah minyak atsiri yang berasal dari hasil destilasi daun tanaman nilam (Pagostemon cablin). Minyak ini merupakan salah satu bahan yang cukup menjanjikan dalam meningkatkan penetrasi obat melalui kulit. Pernyataan ini didukung oleh penelitian yang pernah dilakukan oleh Das \& Ahmed (2017). Kedua peneliti ini 
pernah melakukan pengamatan terhadap spektrum FTIR (Fourier Transform Infrared Spectroscopy) epidermis tikus yang telah ditreatment dengan transdermal patch indometasin yang ditambah dengan minyak nilam sebagai peningkat penetrasi dibandingkan dengan transdermal patch indometasin tanpa peningkat penetrasi. Hasilnya, terlihat bahwa minyak nilam mempengaruhi lipid pada stratum korneum dan juga mengubah konformasi protein pada epidermis. Das \& Ahmed (2017) juga membandingkan transdermal flux dari transdermal patch indometasin dengan penambahan berbagai konsetrasi minyak nilam $(0,05 \%$; $0,25 \% ; 0,5 \% ; 0,75 \%$ dan $1 \%$ ), dengan penambahan 0,05\% DMSO (standar peningkat penetrasi) dan tanpa penambahan peningkat penetrasi. Hasilnya, transdermal patch indometasin yang ditambah $1 \%$ minyak nilam memiliki transdermal flux yang sama dengan transdermal patch indometasin yang ditambah DMSO Dimethyl Sulfoxide).

Minyak nilam memiliki efek antioksidan dan berpotensi untuk dapat mengatasi tanda-tanda penuaan kulit. Komponen utama dari minyak nilam adalah patchouli alcohol (PA). Feng dkk. (2014) pernah melakukan penelitian terhadap efek PA pada perbaikan lesi kulit yang dibuat menua dengan paparan sinar UV. Pada penelitian tersebut, PA dilarutkan dalam suatu pembawa, kemudian dioleskan pada kulit mencit yang dipapar dengan sinar ultra violet (UV) selama 9 minggu berturut-turut. Hasilnya, PA memiliki kemampuan yang baik dalam memulihkan lesi kulit yang rusak akibat paparan sinar UV. Feng dkk menyatakan bahwa hal ini dikarenakan PA memiliki efek anti oksidan dan anti inflamasi, serta dapat menurunkan ekspresi MMP-1 (Matrix metalloproteinase-1) dan MMP-3 (Matrix metalloproteinase-3).

PA mampu menekan kelebihan produksi MMP-1 dan MMP-3 yang diinduksi sinar UV melalui peningkatan aktivitas enzim antioksidan dan penghambatan produksi penanda inflamasi. Hal inilah yang menyebabkan PA dapat memulihkan kerusakan kolagen yang disebabkan oleh paparan sinar UV. Berdasarkan penelitian yang dilakukan oleh Feng dkk, dapat disimpulkan bahwa PA (kandungan terbesar dari minyak nilam) sangat berpotensi sebagai bahan aktif untuk produk kosmetik anti-penuaan kulit, walaupun mekanisme kerjanya masih harus diteliti lebih dalam lagi.

Penambahan minyak nilam ke dalam produk sleeping mask dengan bahan aktif NLC-KoQ10 berpotensi untuk meningkatkan efikasi dari produk tersebut dalam mengatasi tanda-tanda penuaan kulit. Hal ini dikarenakan minyak nilam dapat membantu meningkatkan penetrasi KoQ10 menembus kulit dan dapat menambah efek antioksidan pada produk tersebut.

Sebagai langkah awal pengembangan produk, dilakukanlah uji karakteristik fisik dan stabilitas fisik terhadap sleeping mask yang mengandung NLC-KoQ10 (F1) dan sleeping mask yang mengandung NLC-KoQ10 dengan penambahan $1 \%$ minyak nilam (F2).

\section{BAHAN DAN METODE Bahan}

Koenzim Q10 (Kangcare Bioindustry, Nanjing, Cina), Beeswax (Xiamen Fengston Company, Xiamen, Cina), Oleum Cacao (Balai Penelitian Kopi dan Kakao, Jember, Indonesia), VCO (Biocosmethic, Bonnelles, Perancis), Tween 80 (KAO Corporation, Tokyo, Japan), Span 80 (Sigma Aldrich, Selangor, Malaysia), Propilenglikol (Dow Chemical Pacific, Singapura), Gliserin (Ecogreen Oleochemicals, Batam, Indonesia), Disodium EDTA (Loba Chemie, Mumbai, India), Carbopol 940 (Anhui Newman Fine Chemicals, Anhui, Cina), Trietanolamin (PETRONAS Chemicals Group Berhad, Kuala Lumpur, Malaysia), Nipaguard EHP (Clariant, Muttenz, Swiss), Akuademineral, minyak nilam (Lansida Group, Yogyakarta, Indonesia), $\mathrm{NaH}_{2} \mathrm{PO}_{4} \cdot \mathrm{H}_{2} \mathrm{O}$ (Merck, Gernsheim, Jerman) dan $\mathrm{Na}_{2} \mathrm{HPO}_{4} .2 \mathrm{H}_{2} \mathrm{O}$ (Merck, Gernsheim, Jerman).

\section{Metode \\ Pembuatan sediaan uji}

Sediaan uji akan dibuat dengan 3 tahap: tahap pertama yaitu pembuatan NLC-KoQ10 yang berfungsi sebagai bahan aktif; tahap kedua yaitu pembuatan basis sleeping mask dan tahap ketiga yaitu pembuatan sediaan uji F1 dan F2. Formula sediaan uji dapat dilihat pada Tabel 1 . 
Tabel 1. Formula Uji

\begin{tabular}{|c|c|c|c|}
\hline \multirow{2}{*}{ Bahan } & \multirow{2}{*}{ Fungsi } & \multicolumn{2}{|c|}{$\begin{array}{c}\text { Jumlah yang } \\
\text { digunakan }(\%)\end{array}$} \\
\hline & & $\mathrm{F} 1$ & $\mathrm{~F} 2$ \\
\hline $\begin{array}{c}\text { NLC- } \\
\text { KoQ10 }^{(1)}\end{array}$ & Bahan aktif & 50 & 50 \\
\hline $\begin{array}{c}\text { Basis } \\
\text { sleeping } \\
\text { mask }^{(2)}\end{array}$ & Pembawa & 50 & 49 \\
\hline $\begin{array}{c}\text { Minyak } \\
\text { nilam }\end{array}$ & $\begin{array}{c}\text { Peningkat } \\
\text { penetrasi } \\
\text { KoQ10 }\end{array}$ & - & 1 \\
\hline
\end{tabular}

\section{Keterangan:}

(1) NLC-KoQ10 terdiri dari: KoQ10 (2\%) sebagai bahan aktif, beeswax $(0,990 \%)$ dan oleum cacao $(2,970 \%)$ sebagai lipid padat, VCO $(2,640 \%)$ sebagai lipid cair, Tween $80(13,604 \%)$ dan Span $80 \quad(6,896 \%)$ sebagai surfaktan/emulsifier, propilenglikol $(3,5 \%)$ sebagai kosurfaktan dan dapar fosfat $\mathrm{pH} 6,0 \pm 0,2(\mathrm{ad} 100 \%)$ sebagai fase air.

(2)Basis sleeping mask terdiri dari: gliserin (10\%) sebagai emollient dan humectant, disodium EDTA $(0,3 \%)$ sebagai chelating agent, carbopol 940 $(1,5 \%)$ sebagai gelling agent, trietanolamin $(2,5 \%)$ sebagai alkalizing agent, Nipaguard EHP $(0,5 \%)$ sebagai pengawet dan aquademineral bebas $\mathrm{CO}_{2}$ (ad 100\%) sebagai fase air.

\section{Pembuatan NLC-KoQ10}

NLC-KoQ10 dibuat dengan cara mencampur fase air dan fase minyak dengan alat pengaduk berkecepatan tinggi. Pada penelitian ini digunakan Ultra Turrax IKA®T25 Digital High Shear Homogenizer.

Fase minyak disiapkan dengan cara melelehkan beeswax pada suhu sekitar $70^{\circ} \mathrm{C}$ di hotplate stirrer. Memanaskan tween 80 dan span 80 . Setelah beeswax leleh, oleum cacao dimasukkan ke dalam lelehan beeswax. Setelah oleum cacao melebur, campuran tween 80 dan span 80 dimasukkan ke dalam campuran beeswax dan oleum cacao. KoQ10 didispersikan ke dalam VCO yang telah dipanaskan di suhu $70^{\circ} \mathrm{C}$, diaduk sampai KoQ10 terdispersi homogen. Selanjutnya, campuran VCO dan KoQ10 dimasukkan ke dalam campuran beeswax, oleum cacao, tween 80 dan span 80 .

Fase air terdiri dari propilenglikol dan dapar fosfat. Keduanya dimasukkan ke dalam beaker glass yang sama, kemudian diaduk hingga homogen dan dipanaskan pada suhu $70^{\circ} \mathrm{C}$.

Setelah fase minyak siap, fase air dimasukkan ke dalam fase minyak tetes demi tetes sambil diaduk menggunakan Ultra Turrax IKA®T25 Digital High Shear Homogenizer dengan kecepatan 5000 rpm selama 10 menit. Setelah itu, kecepatan dinaikkan menjadi $16000 \mathrm{rpm}$ dan diaduk selama 2 menit. Setelah selesai, pengadukan dilanjutkan menggunakan hotplate stirrer dengan kecepatan 500 rpm hingga mencapai suhu hotplate stirrer sekitar $25^{\circ} \mathrm{C}$.

\section{Pembuatan basis sleeping mask}

Akuademineral bebas $\mathrm{CO}_{2}$ dan Gliserin dimasukkan dalam beaker glass. Kemudian ditambahkan Disodium EDTA, lalu diaduk hingga Disodium EDTA larut. Nipaguard EHP dimasukkan lalu diaduk hingga homogen. Setelah itu Carbopol 940 ditaburkan di atasnya. Dibiarkan selama 24 jam agar seluruh Carbopol 940 terbasahi dengan sempurna. Setelah itu, ditambahkan trietanolamin (TEA) sedikit demi sedikit sambil diaduk menggunakan IKA Werke Eurostar Power-B Overhead Stirrer (tipe pengaduk: anchor) dengan kecepatan $300 \mathrm{rpm}$ selama 10 menit. $\mathrm{pH}$ sediaan akhir dicek menggunakan $\mathrm{pH}$ meter.

Pembuatan sediaan uji F1, dan F2

Sediaan Uji F1 dibuat dari 50\% NLC-KoQ10 yang dicampur dengan $50 \%$ basis sleeping mask dan diaduk selama 10 menit dengan kecepatan $300 \mathrm{rpm}$ menggunakan IKA Werke Eurostar Power-B Overhead Stirrer dengan tipe pengaduk anchor.

Sediaan Uji F2 dibuat dari 50\% NLC-KoQ10, 49\% basis sleeping mask dan $1 \%$ minyak nilam. Cara pencampurannya: NLC-KoQ10 dicampur dengan basis sleeping mask menggunakan IKA Werke Eurostar Power-B Overhead Stirrer dengan tipe pengaduk anchor. Diaduk selama 8 menit dengan kecepatan 300 rpm. Kemudian memasukkan minyak nilam. Setelah itu, sediaan diaduk kembali selama 2 menit.

\section{Pengujian karakteristik fisik \\ Pengamatan organoleptis}

Pemeriksaan organoleptis dilakukan dengan cara visual, meliputi pemeriksaan warna, bau, dan pemisahan fase yang mungkin terjadi.

\section{Pengukuran nilai $\mathbf{p H}$}

Sebelum melakukan pengujian nilai $\mathrm{pH}$ sampel, terlebih dahulu dilakukan kalibrasi terhadap $\mathrm{pH}$ meter menggunakan larutan standar $\mathrm{pH} 7,0$. Setelah itu, elektroda dibersihkan dan dikeringkan. Langkah selanjutnya adalah mengencerkan sampel dengan akuademineral bebas $\mathrm{CO}_{2}$ dengan perbandingan $1: 9$. Kemudian dicek pHnya menggunakan alat SI Analytics - pH Meter Lab 855.

\section{Pengukuran nilai viskositas}

Nilai viskositas ditentukan menggunakan Brookfield Digital Viscometer DV-I+ (LV and RV series) dengan cone spindle CP-41, kecepatan $100 \mathrm{rpm}$. Caranya, memasukkan $2 \mathrm{~mL}$ sampel yang akan diuji ke dalam cup. Kemudian dibiarkan 15 menit supaya dapat mencapai suhu yang sudah diatur. Lalu dilakukan pengukuran. Setelah proses pengukuran selesai maka 
akan muncul nilai nilai viskositas dalam satuan centipoise ( $\mathrm{cp}$ ) dan \% torque.

\section{Ukuran partikel dan indeks polidispersitas (IP)}

Tahap pertama yaitu pengenceran sediaan. Sebanyak $50 \mathrm{mg}$ sampel ditimbang dengan neraca analitik lalu ditambahkan akuademineral hingga volume 50,0 mL. Diaduk menggunakan magnetic stirrer dengan kecepatan 500 rpm selama 10 menit. Kemudian larutan diambil sebanyak 2,0 $\mathrm{ml}$ lalu ditambah $8 \mathrm{~mL}$ aquademineral. Diaduk kembali dengan keceptan 100 rpm selama 10 menit.

Tahap kedua yaitu penentuan ukuran partikel dan indeks polidispersitas menggunakan Delsa ${ }^{T M}$ nano submicron particle size analyzer. Jumlah tembakan dan replikasi pengamatan pada alat harus ditentukan terlebih dahulu. Setelah itu memasukkan sampel yang sudah diencerkan ke dalam kuvet. Kemudian dimasukkan ke dalam sample holder. Mengamati intensity bar yang tertera pada monitor, jika sudah berwarna kuning atau biru, klik start pada menu bar. Alat akan mulai melakukan pengecekan ukuran partikel dan indeks polidisperistas. Setelah selesai maka akan ada bunyi bip. Setelah itu akan muncul data ukuran partikel dalam satuan nanometer $(\mathrm{nm})$ dan indeks polidispersitas pada layar monitor.

\section{Pengukuran zeta potensial}

Tahap pertama yaitu pengenceran sediaan. Sebanyak $50 \mathrm{mg}$ sampel ditimbang dengan neraca analitik lalu ditambahkan akuademineral hingga volume 50,0 mL. Diaduk menggunakan magnetic stirrer dengan kecepatan 500 rpm selama 10 menit. Kemudian larutan diambil sebanyak 2,0 $\mathrm{mL}$ lalu ditambah $8 \mathrm{ml}$ aquademineral. Diaduk kembali dengan keceptan 100 rpm selama 10 menit.

Tahap kedua yaitu menentukan zeta potensial sampel menggunakan Zetasizer Nano (Malvern Instrument). Melakukan setting alat untuk pengukuran zeta potensial. Kemudian memasukkan sampel yang sudah diencerkan ke dalam kuvet lalu dimasukkan ke dalam sample holder. Klik start. Setelah alat selesai melakukan pengukuran, akan muncul nilai zeta potensial sediaan dengan satuan milivolt $(\mathrm{mV})$ pada layar monitor.

\section{Pengamatan Morfologi}

Tahap pertama yaitu pengenceran sediaan : $50 \mathrm{mg}$ sampel ditimbang dengan neraca analitik lalu ditambahkan aquademineral hingga volume 50,0 mL. Diaduk menggunakan magnetic stirrer dengan kecepatan 500 rpm selama 10 menit. Kemudian larutan diambil sebanyak 2,0 $\mathrm{mL}$ lalu ditambah $8 \mathrm{~mL}$ akuademineral. Diaduk kembali dengan keceptan 100 rpm selama 10 menit.

Sampel yang sudah diencerkan diteteskan pada grid. Ditunggu beberapa saat hingga kering setelah itu diwarnai dengan uranil asetat. Kemudian ditunggu hingga kering setelah itu diamati dengan alat Jeol JEM1400 Transmission Electron Microscope dengan perbesaran 40.000 kali.

\section{Pengujian stabilitas fisik}

Pada penelitian ini dilakukan uji stabilitas fisik real time terhadap $\mathrm{F} 1$ dan $\mathrm{F} 2$ yang disimpan dalam ruangan yang dilengkapi $A C$ (Air Conditioner) dengan suhu $20^{\circ} \mathrm{C} \pm 1{ }^{\circ} \mathrm{C}$, Relative Humidity $(R H) 65 \%$ dan terhindar dari cahaya matahari. Pengujian dilakukan selama 3 bulan (90 hari). Aspek yang dinilai pada uji stabilitas yang dilakukan adalah organoleptis (aroma, warna, pemisahan), nilai $\mathrm{pH}$ dan nilai viskositas. Pengujian dilakukan pada hari ke-0, 14, 30, 60 dan 90.

\section{HASIL DAN PEMBAHASAN}

\section{Hasil uji karakteristik fisik}

Pada NLC-KoQ10, Perbandingan beeswax dan oleum cacao yang digunakan adalah 25 : 75. Pemilihan ini didasarkan pada penelitian yang telah dilakukan oleh Erawati dkk. (2019) yang menyatakan bahwa NLC minyak kemiri yang dibuat dengan kombinasi lipid padat beeswax dan oleum cacao dengan rasio $25: 75$ memiliki real time stability yang paling baik dibanding dengan penggunaan beeswax tunggal atau oleum cacao tunggal.

Hasil uji karakteristik fisik menunjukkan bahwa NLC-KoQ10 memiliki karakteristik fisik yang baik. Sediaan ini terlihat homogen secara visual (dapat dilihat pada Gambar 1). Nilai pH dari sedian ini adalah 6,066 \pm 0,006. Nilai ini masuk dalam rentang $\mathrm{pH}$ kulit, yaitu 4,5 - 6,8 (Lambers dkk., 2006). Partikel dari sediaan ini berbentuk sferis (dapat dilihat pada Gambar 2); ukuran partikelnya $153,7 \pm 7,4 \mathrm{~nm}$. Nilai ini memenuhi syarat ukuran partikel NLC, yaitu di bawah $1000 \mathrm{~nm}$ (Khosa dkk., 2018). Nilai indeks polidispersitasnya yaitu 0,279 \pm 0,062. Menurut Soeratri dkk. (2019), nilai polidispersitas yang kurang dari 0,3 menandakan bahwa ukuran partikel sistem NLC homogen.

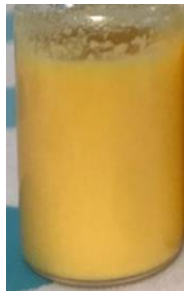

Gambar 1. NLC-KoQ10 


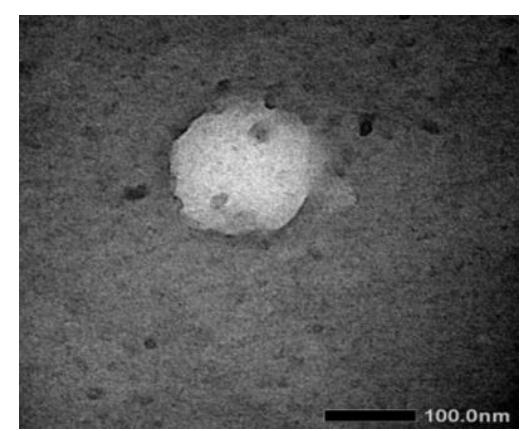

Gambar 2. Hasil pengamatan morfologi partikel NLC-KoQ10 menggunakan TEM pada Skala $100 \mathrm{~nm}$ dan Perbesaran 40.000 Kali

Berdasarkan uji karakteristik fisik, diketahui bahwa hydrogel memiliki warna jernih, homogen, tidak berbau dan memiliki konsistensi yang kental. Hydrogel yang dibuat, diharapkan memiliki pH 6,0 $\pm 0,5$. Spesifikasi ini mengacu pada $\mathrm{pH}$ optimal Carbopol 940 untuk membentuk konsistensi gel yang baik. Carbopol 940 adalah gelling agent yang akan membentuk masa gel dengan viskositas yang kental jika berada pada suasana pH 6 - 11 (Barry, 1983). Carbopol 940 pada dasarnya memiliki sifat asam. Oleh karena itu, perlu ditambahkan suatu bahan yang dapat meningkatkan $\mathrm{pH}$, seperti kalium hidroksida, natrium hidroksida ataupun trietanolamin. Pada penelitian ini dipilih trietanolamin (TEA) karena bahan ini bukan merupakan elektrolit seperti kalium hidroksida dan natrium hidroksida sehingga tidak mempengaruhi zeta potensial NLC (Doktorovova \& Souto, 2009). Dari uji pH, diketahui bahwa hydrogel memiliki pH 6,080 $\pm 0,044$.

Tabel 2. Hasil pengamatan karakteristik fisik F1 dan F2

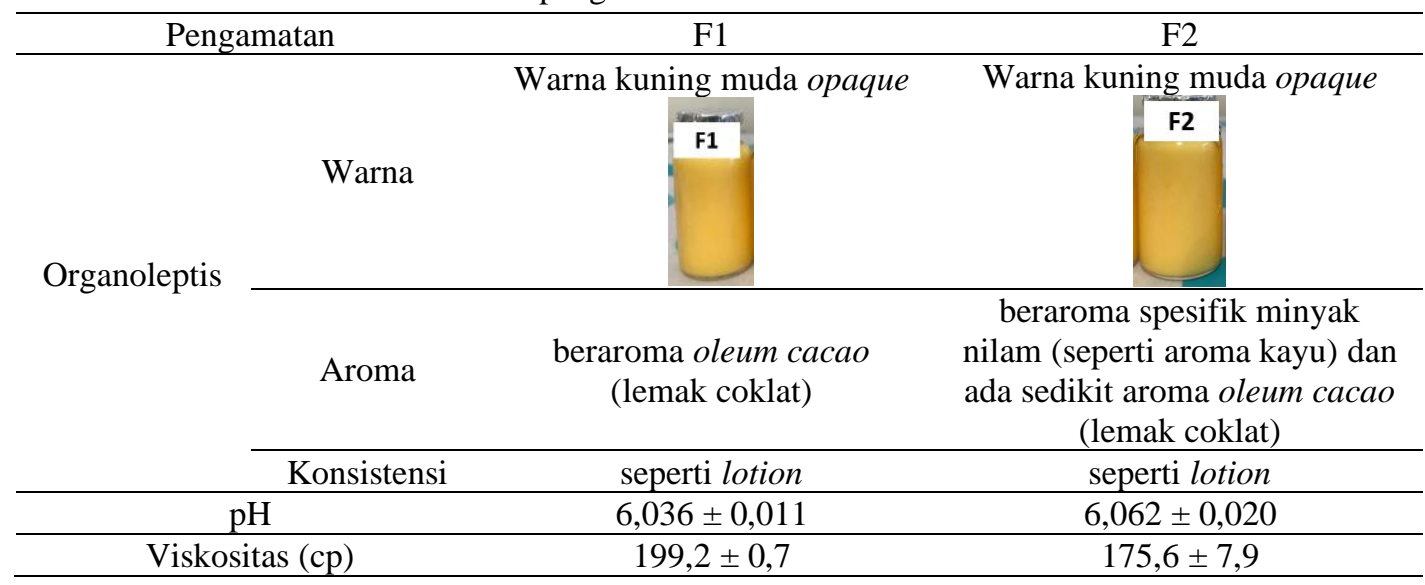

Data uji karakteristik fisik F1 dan F2 dapat dilihat pada Tabel 2. Perbedaan aroma dari F1 dan F2 dikarenakan pada F2 ditambahkan minyak nilam sedangkan pada F1 tidak. Pada F2, aroma oleum cacao (lemak coklat) tidak dapat ditutupi dengan sempurna oleh minyak nilam karena minyak nilam termasuk minyak atsiri kelompok base note. Minyak atsiri yang termasuk dalam kelompok ini memiliki aroma yang cenderung lembut dan aromanya baru akan tercium setelah beberapa detik dihirup (Totilo, 2013).

Uji karakteristik nilai $\mathrm{pH}$ menunjukkan bahwa F1 memiliki nilai pH 6,036 $\pm 0,011$ sedangkan $\mathrm{F} 2$ memiliki $\mathrm{pH} 6,062 \pm 0,020$. Kedua formula memiliki nilai $\mathrm{pH}$ yang masuk dalam $\mathrm{pH}$ spesifikasi sediaan akhir, yaitu $6,0 \pm 0,5$ dan masuk dalam rentang $\mathrm{pH}$ kulit 4,5 - 6,8 (Lambers dkk., 2006). Nilai pH yang terlalu asam atau terlalu basa dapat menyebabkan iritasi pada kulit.

Uji karakteristik nilai viskositas, menunjukkan bahwa F1 memiliki viskositas 199,2 $\pm 0,7 \mathrm{cP}$ dan F2 memiliki viskositas $175,6 \pm 7,9 \mathrm{cP}$. Setelah diuji secara statistik menggunakan Independent Sample $t$ Test dengan $\alpha=0,05$, disimpulkan bahwa ada perbedaan bermakna antara nilai viskositas F1 dengan F2. F2 memiliki nilai viskositas yang lebih rendah daripada $\mathrm{F} 1$ kemungkinan dikarenakan F2 mengandung hydrogel 49\% sedangkan F1 mengandung hydrogel 50\%. Pada F2 ada penambahan $1 \%$ minyak nilam sehingga mengurangi persentase pembawa (hydrogel). Hal inilah yang kemungkinan membuat keduanya memiliki perbedaan nilai viskositas.

\section{Hasil uji stabilitas fisik}

Pada penelitian ini dilakukan uji stabilitas fisik secara real time pada suhu $20 \pm 1{ }^{\circ} \mathrm{C}$ dan RH $65 \%$. Sampel disimpan pada vial yang tertutup rapat dan terlindung dari cahaya. Pengujian dilakukan pada hari ke-0, 14, 30, 60 dan 90. Aspek yang dinilai pada uji stabilitas adalah organoleptis, ada atau tidaknya pemisahan, $\mathrm{pH}$ dan viskositas.

Berdasarkan pengamatan organoleptis pada hari ke0, 14, 30, 60 dan 90 diketahui bahwa F1 dan F2 tidak mengalami perubahan. Kedua formula tetap memiliki warna kuning muda opaque (Gambar 3), dan memiliki 
konsistensi seperti lotion. Aroma kedua formula juga tetap. F1 tetap memiliki aroma oleum cacao (lemak coklat), F2 tetap memiliki aroma minyak nilam (aroma kayu) dengan sedikit aroma oleum cacao (lemak coklat). Tidak didapati adanya pemisahan pada kedua formula, sediaan tetap homogen sampai penyimpanan 90 hari.

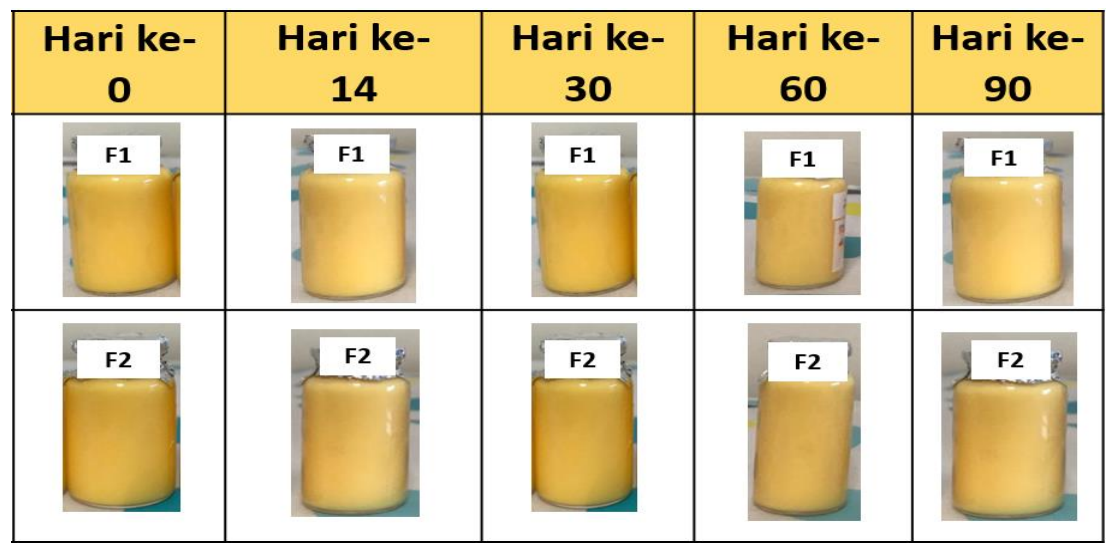

Gambar 3. F1 dan F2 pada pengamatan di hari ke-0, 14, 30, 60 dan 90

Pengamatan nilai $\mathrm{pH}$ pada hari ke-0, 14, 30, 60 dan 90 memberikan informasi bahwa nilai $\mathrm{pH}$ F1 dan F2 relatif stabil. Hasil pengamatan dapat dilihat pada Gambar 4. Nilai pH pada semua formula dan semua titik pengamatan masih dalam rentang $\mathrm{pH}$ spesifikasi sediaan akhir, yaitu $6,0 \pm 0,5$. Nilai $\mathrm{pH}$ hasil pengamatan juga masih dalam rentang $\mathrm{pH}$ kulit 4,5 - 6,8 (Lambers dkk., 2006). Sehingga sediaan aman untuk digunakan.

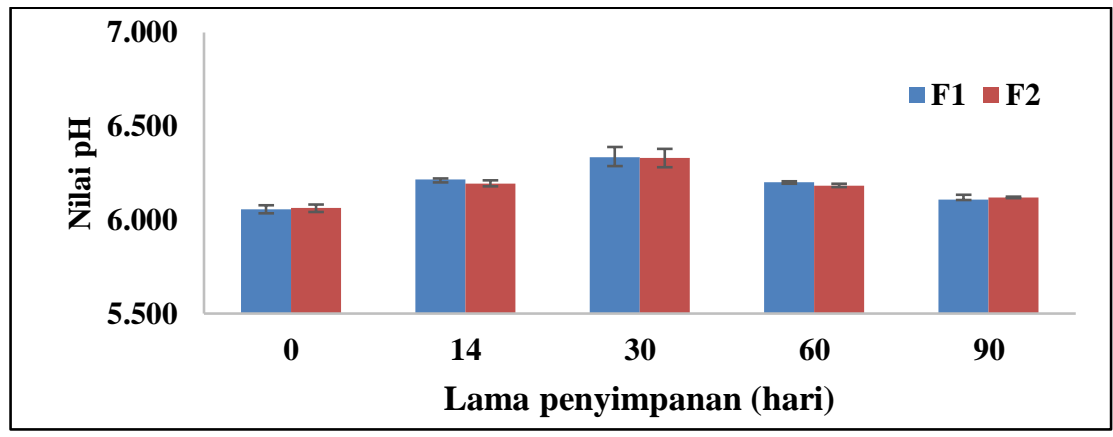

Gambar 4. Histogram hasil pengukuran nilai pH F1 dan F2 pada hari ke-0, 14, 30, 60 dan 90

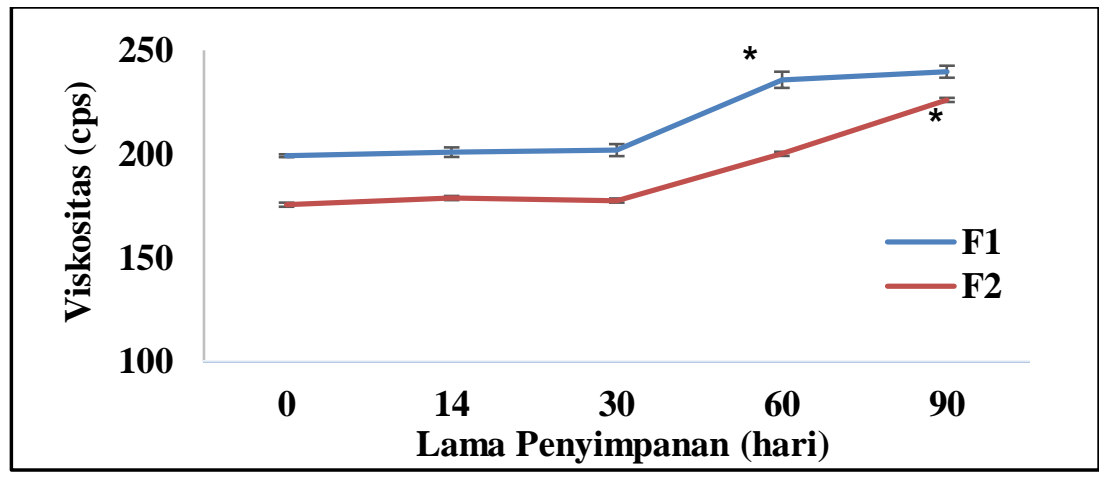

Gambar 5. Grafik hasil pengukuran nilai viskositas F1 dan F2 pada hari ke-0, 14, 30, 60 dan 90

Hasil pengamatan nilai viskositas pada hari ke-0, 14, 30, 60 dan 90 untuk F1 dan F2 dapat dilihat pada Gambar 5. Hasil pengamatan dianalisa secara statistik menggunakan Anova One Way dengan $\alpha=0,05$ dan dilanjutkan dengan uji Post Hock Tukey HSD untuk mengetahui kelompok apa saja yang berbeda bermakna.
Dari uji tersebut, diketahui bahwa nilai viskositas F1 mengalami peningkatan pada hari ke-60. Sedangkan untuk F2, peningkatan viskositas secara bermakna terjadi pada hari ke-90

Kenaikan nilai viskositas pada sediaan selama penyimpanan kemungkinan dikarenakan persentase 
humektan dalam sediaan yang cukup kecil sehingga air dari sediaan banyak yang menguap. Hal ini menyebabkan sediaan menjadi lebih kental dan nilai viskositasnya meningkat. Penambahan humektan pada suatu sediaan topikal dapat memberi keuntungan ganda. Ketika sediaan topikal diaplikasikan pada kulit, humektan yang ada di dalam sediaan tersebut akan menahan penguapan air dari kulit dan mengikat air yang ada di udara, sehingga kadar air pada kulit tetap terjaga (Mitsui, 1998). Sebelum sediaan diaplikasikan ke kulit, humektan dapat menjaga kadar air pada sediaan sehingga kadar air dalam sediaan tetap terjaga (Larranaga, 2016; Mitsui, 1998). Pada sediaan akhir, baik itu F1 ataupun F2, persentase gliserin sekitar 5\% dan persentase propilenglikol 1,75\%. Persentase kedua humektan ini kemungkinan masih kurang untuk mempertahankan kadar air pada sediaan selama penyimpanan.

\section{KESIMPULAN}

Berdasarkan uji karakteristik fisik, disimpulkan bahwa F1 (tanpa minyak nilam) dan F2 (dengan 1\% minyak nilam) memiliki perbedaan aroma dan viskositas. Berdasarkan uji stabilitas fisik, disimpulkan bahwa F2 lebih stabil daripada F1.

\section{DAFTAR PUSTAKA}

Bao, K., Zhang, C., Xie, S., Feng, G., Liao, S., Cai, L., He, J., Guo, Y. \& Jiang, C. (2019). A Simple and Accurate Method for the Determination of Related Substances in Coenzyme Q10 Soft Capsules. Molecules; 24; 1-14.

Barry, B. W. (1983). Dermatological Formulation. New York: Marcel Dekker Inc.

Campa, M. \& Baron, E. (2018). Anti-aging Effects of Select Botanicals: Scientific Evidence and Current Trends. Cosmetics; 5; 1-15.

Das, A. \& Ahmed, A. B. (2017). Formulation and Evaluation of Transdermal Patch of Indomethacin Containing Nilam Oil as Natural Penetration Enhancer. Asian Journal of Pharmaceutics and Clinical Research; 10; 320-325.

Doktorovova, S. \& Souto, E. B. (2009). Nanostructured Lipid Carrier-Based Hydrogel Formulations for Drug Delivery: a Comprehensive Review. Expert Opinion Drug Delivery; 6; 165-176.

Erawati, T., Putri, D. A., Maharani, A. S., Rosita, N. \& Soeratri, W. (2019). Characteristics and Stability of Nanostructured Lipid Carrier (NLC) Aleurites Moluccana Seed Oil (AMS oil) Using Various Combinations of Beeswax and Oleum Cacao.
International Journal of Drug Delivery Technology; 9; 94-97

Fang, C. (2013). Nanostructured Lipid Carriers (NLCs) for Drug Delivery and Targeting. Recent Patents on Nanotechnology; 7; 41-55.

Feng, X., Yu, X., Li, W., Kong, S., Liu, Y., Zhang, X. \& Lin, Z. (2014). Effect of Topical Application of Patchouli Alcohol on the UV-induced Skin Photoaging in Mice. European Journal of Pharmaceutical Sciences; 63; 113-123.

Kaur, S., Nautyal, U., Singh, R., Singh, S. \& Devi, A. (2015). Nanostructure Lipid Carrier (NLC): the New Generation of Lipid Nanoparticle. Asian Pacific Journal of Health Sciences; 2; 76-93.

Khosa, A., Reddi, S. \& Saha, R. N. (2018). Nanostructured Lipid Carriers for Site-specific Drug Delivery. Biomedicine \& Pharmacotherapy; 103; 598-613.

Lambers, H., Piessens, S., Bloem, A., Pronk, H., \& Finkel, P. (2006). Natural Skin Surface pH is on Average Below 5, Which is Beneficial for Its Resident Flora. International Journal of Cosmetic Science; 28; 359-370.

Larranaga, M. D., Lewis, SR., R. J. \& Lewis, R. A. (2016). Hawley's: Condensed Chemical Dictionary. Hokoben: John Wiley \& Sons, Inc.

Lucangioli, S. \& Tripodi, V. (2012). The Importance of the Formulation in the Effectiveness of Coenzyme Q10 Supplementation in Mitochondrial Disease Therapy. Der Pharmacia Sinica; 3; 406-407.

Mitsui, T. (1998). New Cosmetic Science. Amsterdam: Elsevier Science B.V.

Muller, R. H., Staufenbiel, S. \& Keck, C. M. (2014). Lipid Nanoparticles (SLN, NLC) for Innovative Consumer Care \& Household Products. Household and Personal Care Today; 9; 18-24.

Nilforoushzadeh, M. A., Amirkhani, M. A., Zarrintaj, P., Moghaddam, A. S., Mehrabi, T., Alavi, S. \& Sisakht, M. M. (2018). Skin Care and Rejuvination by Cosmeceutical Facial Mask. Journal of Cosmetic Dermatologi; 17; 693-702.

Sanad, R. A, Abdelmalak, N. S., Elbayoomy, T. S. \& Badawi, A. A. (2010). Formulation of a Novel Oxybenzone-Loaded Nanostructured Lipid Carriers (NLCs). The American Association of Pharmaceutical Scientists Journal; 11; 16841694.

Science, P. (2009). Skin and Nail: Barrier Function, Structure, and Anatomy Considerations for Drug Delivery. Cleveland: Lubrizol Life Science.

Soeratri, W., Hidayah, R. \& Rosita, N. (2019). Effect of 
Combination Soy Bean Oil and Oleic Acid to Characteristic, Penetration, Physical Stability of Nanostructure Lipid Carrier Resveratrol. Folia Medica Indonesiana; 55; 213-222.

Totilo, R. P. (2013). Therapeutic Blending with Essential Oil. Petersburg: Rebeca at the Well Foundation.

Yang, L., Ganse, L., \& Jimenez, S. (2019). The Korean
Skin Care Bibble. London: Octopus Publishing Group.

Yue, Y., Zhou, H., Liu, G., Li, Y., Yan, Z. \& Duan, M. (2010). The Advantages of A Novel CoQ10 Delivery System in Skin Photo-protection. International Journal of Pharmaceutics; 392; 57 63. 